\title{
STASIUN RISET BEKANTAN PADA LAHAN BASAH
}

\author{
Aisyah Melati \\ Program Studi Teknik Arsitektur Fakultas Teknik Universitas Lambung Mangkurat \\ 1610812120002@mhs.ulm.ac.id
}

\author{
Bani Noor Muchamad \\ Program Studi Arsitektur Fakultas Teknik Universitas Lambung Mangkurat \\ bani.nm@ulm.ac.id
}

\begin{abstract}
ABSTRAK
Lahan basah merupakan habitat alami hewan endemik Kalimantan Selatan, yaitu bekantan (Nasalis larvatus). Hewan primata tersebut menjadi salah satu indikator dalam pelestarian lahan basah, namun sekarang bekantan berstatus terancam punah yang berarti lahan basah sebagai alaminya juga mengalami kerusakan. Hal ini membuat Yayasan Sahabat Bekantan Indonesia (SBI) khawatir terhadap pelestarian primata tersebut yang berstatus terancam punah di samping banyaknya peneliti asing yang tertarik dengan bekantan sehingga juga memperlemah status bekantan sebagai hewan endemik.

SBI menginginkan bekantan yang ada di Kalimantan Selatan ini dapat menjadi identitas daerah beserta dengan ekosistem lahan basah yang merupakan habitat hidup bekantan. Oleh karena itu permasalahan mendasar pada Perancangan Stasiun Riset Bekantan pada Lahan Basah adalah bagaimana rancangan stasiun riset bekantan pada lahan basah yang selaras dengan kondisi alam sekitarnya sehingga dapat menjadi identitas kawasan tersebut. Penyelesaian masalah tersebut dipecahkan melalui metode metabolisme-organik dan metode identitas visual-metafora. Metode metabolisme-organik merupakan solusi dalam permasalahan keselarasan bangunan dengan alam, sedangkan metode identitas visual-metafora merupakan solusi dalam permasalahan identitas kawasan. Berdasarkan kedua metode tersebut konsep yang diajukan untuk perancangan ini adalah konsep "subject-object interaction" yang diwujudkan melalui konsep "wetland ecology". Konsep "subject-object interaction and wetland ecology" ini merupakan konsep yang mengangkat interaksi antara peneliti dan organisme lahan basah seperti bekantan dengan memasukan unsur lahan basah tersebut ke rancangan stasiun riset ini.
\end{abstract}

Kata kunci: Stasiun riset, bekantan, lahan basah, pelestarian, metabolisme, organik, identitas visual, metafora, subject-object interaction, wetland ecology

\begin{abstract}
Wetlands are a natural habitat for endemic animals of South Kalimantan, namely proboscis monkeys (Nasalis larvatus). These primates are one indicator in wetlands conservation, but now the status of proboscis monkeys is endangered which means wetlands are naturally also damaged. This makes The Indonesian Proboscis Monkey Friends Foundation worried about the preservation of these
\end{abstract}


primates who are endangered in a side the number of foreign researchers who are interested in proboscis monkeys so it also weakens status proboscis monkeys as endemic animals.

The Indonesian Proboscis Monkey Friends Foundation wants the proboscis monkey in South Kalimantan to become an identity in the area along with the wetland ecosystem which is the habitat of proboscis monkeys. Therefore a fundamental problem with the design of the Proboscis Monkey Research Station on Wetlands is how the design of the proboscis research station on wetlands is in harmony with natural conditions around it so that it can become the identity of the region. Settlement the problem was solved through the metabolism-organic method and the visual identity-metaphor method. The metabolism-organic method is the solution to the problem of harmony building with nature, while the visual identity-metaphor method is the solution in the matter of regional identity. Based on the two methods, the concept proposed for this design is the concept of "subject-object interaction" which is realized through the concept of "wetland ecology". This concept of "subject-object interaction and wetland ecology" is a concept that elevates interactions between researchers and wetland organisms such as proboscis monkeys by entering the wetland elements into the design of this research station.

Keywords: Research Station, proboscis monkey, wetlands, conservation, metabolism, organic, visual identity, metaphor. subject-object interaction, wetland ecology

\section{PENDAHULUAN}

Lahan basah merupakan wilayah daratan bumi yang mempunyai kandungan air atau yang digenangi air secara permanen maupun sementara. Sekitar 600 juta orang untuk memenuhi kebutuhan hidupnya bergantung dengan lahan basah dan 6\% dari luas permukaan bumi ditutupi oleh lahan basah termasuk Indonesia yang di dalamnya mempunyai 30,3 juta ha lahan basah. Menurut para ahli, sekarang lahan basah telah hilang sekitar $64 \%$ dari permukaan bumi ini sejak tahun 1900 (VOA, 2015).

Semua air tawar di bumi ini berasal dari lahan basah yang dapat memurnikan air dari polusi serta dapat menyimpan karbon. Lahan basah sekarang telah mengalami kerusakan yang diakibatkan oleh pengelolaan lahan basah yang kurang tepat dan sulit dipulihkan ke kondisi semula ketika sudah mengalami pencemaran. Di Indonesia sendiri telah diperkirakan $60 \%$ sungai mengalami pencemaran dan 10 tahun terakhir ini jutaan hektar rawa gambut di Sumatra dan Kalimantan telah terbakar sehingga terjadi penurunan keanekaragaman hayati serta penurunan kualitas air dan udara (Harahap, 2018).

Lahan basah juga dimanfaatkan untuk habitat para hewan. Salah satu hewan yang dapat hidup di lahan basah adalah hewan primata bekantan (Nasalis larvatus). Primata seperti bekantan ini dapat dijadikan indikator dalam mengelola hutan dan menentukan strategi konservasi lahan basah. Sekarang ini bekantan berstatus konservasi endangered (IUCN,2008) dengan Appendix I CITIES (Convention on Trade in Endangered Species of Wild Fauna and Flora) sehingga menjadikan primata tersebut terancam keberadaannya dan perlu upaya konservasi yang tinggi. Menurut McNeely et al. (1990) habitat bekantan berkurang seluas $40 \%$ dari $29.500 \mathrm{Km}^{2}$ dengan $4,1 \%$ kawasan yang berstatus konservasi (Bismark, 2009).

Berdasarkan SK Gubernur Kalimantan Selatan No. 29 Tahun 1990 tanggal 16 Januari 1990, bekantan merupakan satwa endemik di Pulau Kalimantan yang telah ditetapkan sebagai fauna maskot Provinsi Kalimantan Selatan. Primata tersebut tersebar di tiga negara yaitu Brunei Darussalam, Malaysia (Sabah, Sarawak), dan Indonesia (Kalimantan). Di Kalimantan sendiri ada 153 titik yang menjadi habitat alami bekantan dengan berbagai macam tipe habitatnya seperti, kawasan mangrove, rawa air tawar, rawa galam bahkan perkebunan karet, tetapi dengan banyaknya terjadi kerusakkan habitat aslinya, bekantan sekarang mengalami penurunan populasi di alam liar. Ada sekitar $47 \%$ habitat asli bekantan telah lenyap dan selama 36-40 tahun terakhir telah terjadi penurunan 
populasi bekantan sebanyak $50 \%-80 \%$ yang menandakan bahwa bekantan tidak dapat beradaptasi dengan kerusakan habitat (Rezeki, 2016).

Di Kalimantan Selatan sendiri terdapat beberapa wilayah habitat alami bekantan di lahan basah seperti di Pulau Bakut dan Pulau Curiak. Menurut SBI (Sahabat Bekantan Indonesia) di Pulau Bakut pada tahun 2018 berjumlah 46 ekor dari 60 ekor pada pendataan sebelumnya, sedangkan di Pulau Curiak terdapat 2 kelompok bekantan. Jumlah bekantan di Pulau Curiak diperkirakan sekitar 18-22 ekor bekantan. Di dekat pulau tersebut juga telah berdiri Stasiun Riset Bekantan dan Ekosistem Lahan Basah yang sederhana sebagai tempat pusat penelitian, edukasi, dan restorasi kawasan lahan basah yang dikelola bersama antara oleh Yayasan SBI dan ULM (Universitas Lambung Mangkurat) serta digunakan sebagai tempat penelitian bagi para peneliti dari dalam negeri maupun luar negeri.

\section{A. Tujuan Rancangan}

Stasiun riset bekantan pada lahan basah merupakan tempat penelitian untuk ekosistem lahan basah. Stasiun tersebut terletak di Pulau Curiak, Kec. Marabahan Baru, Kab. Barito Kuala, Kalimantan Selatan. Pendiri atau penggagas dari stasiun riset ini adalah Ferry F. Hoesain bersama Amalia Rezeki. Mereka berdua juga merupakan founder dari Yayasan Sahabat Bekantan Indonesia.

Yayasan Sahabat Bekantan Indonesia adalah sebuah lembaga pelestarian bekantan di bawah naungan Kementerian Lingkungan Hidup dan Kehutanan RI. Yayasan tersebut didirikan pada November 2013 dalam rangka membantu pemerintah dalam melindungi bekantan di Kalimantan Selatan. Bekantan hanya mampu melahirkan 1 ekor dalam kurun waktu sekitar 1 tahun. Perkembangbiakan yang rendah ini juga menyebabkan populasi bekantan menurun di samping perburuan liar yang marak dan kebakaran hutan, tetapi menurut Amalia populasi bekantan di Pulau Bakut telah mengalami peningkatan dari tahun
2012 hingga 2015 yaitu dari kisaran 30 ekor menjadi sekitar 42 ekor.

Pada tahun 2018 kegiatan Sahabat Bekantan Indonesia (SBI) berpindah ke Pulau Curiak karena di Pulau Bakut dijadikan sebagai tempat wisata alam yang dapat membatasi ruang gerak yayasan tersebut. Di Pulau Curiak juga terdapat bekantan yang berjumlah 2 kelompok bekantan dan jika ditotal jumlah bekantan di pulau ini berkisar 22 ekor bekantan. Hewan endemik Kalimantan Selatan ini juga tersebar di daerah lainnya yang belum terdata dan status bekantan masih dalam keadaan terancam punah.

Melihat kondisi bekantan saat ini membuat banyak peneliti asing yang tertarik dengan hewan endemik tersebut. Banyak dari mereka yang datang ke Kalimantan Selatan untuk melakukan berbagai riset tentang bekantan maupun lahan basah. Hal ini menimbulkan kekhawatiran bagi $\mathrm{SBI}$ dengan banyaknya orang asing yang lebih peduli dengan bekantan dibandingkan dengan masyarakat Kalimantan Selatan sendiri. Bisa saja hewan endemik Kalimantan Selatan ini menjadi kepemilikan atau diakui oleh orang asing dan bukan dari Kalimantan Selatan, jika melihat kondisi masyarakat saat ini yang kurang memiliki kesadaran terhadap potensi daerahnya.

SBI menginginkan bekantan yang ada di Kalimantan Selatan ini dapat menjadi identitas daerah ini beserta dengan ekosistem lahan basah yang merupakan habitat hidupnya. Jika identitas tersebut terus dipertahankan dan dikembangkan, maka upaya pelestarian bekantan dan ekosistem lahan basah di Kalimantan Selatan akan terus bertahan. Selain itu, dengan menjadi identitas suatu daerah maka akan semakin meningkat pula tingkat kesadaran masyarakat sekitar tentang pentingnya bekantan dan habitat alaminya. Kesadaran masyarakat tentang hal tersebut dapat memicu rasa ingin ikut andil seseorang serta keinginan berpartisipasi dalam pelestarian dan merawat bekantan dengan habitatnya.

Dengan demikian dapat disimpulkan tujuan rancangan dari Stasiun Riset Bekantan pada Lahan Basah ini adalah 
untuk menghasilkan rancangan arsitektur yang dapat menjadi identitas daerah Kalimantan Selatan agar dapat meningkatkan kelestarian bekantan dan lahan basah sebagai habitat alaminya. Pelestarian bekantan ini dimulai dari menyelamatkan habitat alami bekantan itu sendiri yang umumnya berada di lahan basah hutan mangrove. Selain itu, hutan mangrove juga dapat menyimpan karbon lebih banyak dari hampir semua ekosistem di bumi. Penyimpanan karbon pada ekosistem mangrove berpotensi pula sebagai imitasi pemanasan global, menjadikan indikator penting bagi pelestarian lahan basah dan bekantan.

\section{B. Fakta dan Analisis}

Lokasi Perancangan Stasiun Riset Bekantan pada Lahan Basah berada di Pulau Curiak, Marabahan Baru, Kabupaten Barito Kuala, Kalimantan Selatan. Pulau ini terletak berdekatan dengan Pulau Bakut dan Jembatan Barito yang terbentuk dari delta Sungai Barito sekitar tahun 80an. Pulau tersebut juga termasuk wilayah yang dilindungi sehingga diperlukan zona pelindung sebagai pendukung wilayah tersebut.

Pulau Curiak menjadi wilayah inti daerah yang dilindungi karena ekosistem dan habitat bekantan masih alami. Pulau Bakut juga menjadi zona inti yaitu sebagai zona yang dikonservasi oleh pemerintah, sedang kawasan di sekitar bawah Jembatan Barito menjadi zona buffering, yaitu zona penyangga dan sebagai peralihan atau area penerima. Dalam penzonaan di stasiun riset ini semakin ke zona inti maka desain, bangunan, dan aktivitas semakin dibatasi serta meminimalkan kegiatan yang membawa massa banyak.

Di Pulau Curiak, Pulau Bakut dan kawasan di sekitar bawah Jembatan Barito masih memiliki ekosistem lahan basah yang baik yang didominasi oleh vegetasi mangrove berupa pohon rambai. Pohon rambai merupakan makanan bagi bekantan yang terdapat di Pulau Curiak dan Pulau Bakut sedangkan di area bawah Jembatan Barito tidak terdapat bekantan karena tempat tersebut merupakan tempat yang didominasi kehidupan manusia.

Kawasan di sekitar bawah Jembatan Barito ini dimaksimalkan menjadi wilayah ekosistem lahan basah, area penerima, dan rehabilitasi bekantan. Selama ini Pusat Rehabilitasi Bekantan berada di Banjarmasin, Jl. Sultan Adam. Pusat rehabilitasi tersebut memiliki jarak sekitar 1 jam 30 menit dari Jembatan Barito sehingga diperlukan pula tempat yang lebih dekat dengan area inti konservasi agar memudahkan jika ada kondisi darurat.

Daerah inti di Pulau Curiak sudah berdiri stasiun riset bekantan sederhana yang didirikan oleh SBI dan daerah inti di Pulau Bakut menjadi taman wisata alam sehingga memiliki fasilitas cukup baik seperti adanya titian, dermaga, gerbang penerima dan sebagainya. Kondisi di 2 pulau tersebut dimaksimalkan untuk kegiatan kepentingan penelitian bekantan dan ekosistem lahan basah. Pulau Curiak dan Pulau Bakut akan menjadi wilayah perancangan stasiun riset bekantan pada lahan basah karena 2 wilayah ini masih memiliki bekantan dan ekosistem lahan basah yang dominan. Akses menuju ke 2 pulau tersebut hanya melalui jalur sungai sehingga hal ini dapat membatasi massa yang datang ke daerah konservasi ini.

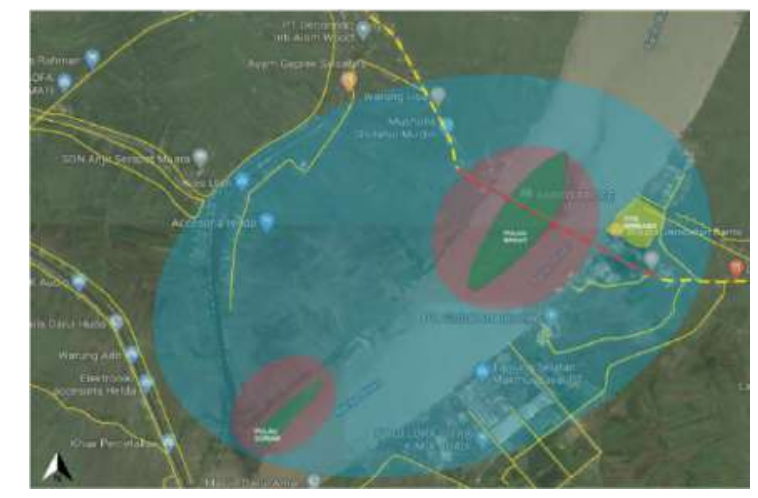

Gambar 1. Zonasi kawasan stasiun riset Sumber: Penulis 2020

Dengan demikian, di dalam Perancangan Stasiun Riset Bekantan pada Lahan Basah ini dirancang menjadi 2 zona konservasi, yaitu zona inti dan zona buffering. Masing-masing zona memiliki fungsi yang berbeda sesuai kondisi site 
sehingga kebutuhan untuk setiap zona juga berbeda. Pulau Curiak dan Pulau Bakut merupakan zona inti sebagai zona konservasi yang difungsikan sebagai tempat khusus peneliti dan akses menuju ke tempat tersebut pun dibatasi. Zona buffering sebagai tempat penelitian namun masih dapat diakses oleh orang umum sebab menjadi daerah penerima sehingga desain dan rancangan di daerah ini dapat lebih menonjol agar dapat menarik publik.

\section{Kebutuhan}

Dalam kondisi sekarang Stasiun Riset Bekantan di Pulau Curiak hanya menerima 5 kunjungan dalam menerima sehari. Hal ini dibatasi karena mengingat wilayah tersebut merupakan wilayah dilindungi dan dilestarikan, sedangkan Pulau Bakut merupakan wilayah yang dikonservasi dengan habitat asli bekantan. Hal ini menyebabkan wilayah inti tersebut didesain dengan meminimalkan perhatian para satwa liar dan perlu tersamarkan keberadaannya, tetapi tetap memperhatikan aktivitas manusia di sana agar penelitian dapat berjalan dan tidak mengganggu habitat para satwa di kawasan.

Area di sekitar bawah Jembatan Barito merupakan tempat gerbang stasiun riset sehingga wilayah ini masih banyak pengunjung yang datang dengan batasan kunjungan minat khusus. Tempat ini perlu didesain dengan mempertimbangkan hal tersebut sehingga menjadi daerah penerima dan sekaligus sebagai tempat rehabilitasi bekantan serta dapat didesain dengan mencolok untuk menarik masyarakat terhadap bekantan dan lahan basah.

Selain itu, dari ketiga titik kawasan yaitu, Pulau Curiak, Pulau Bakut dan area di sekitar bawah Jembatan Barito masih belum ada tempat yang layak untuk para peneliti yang datang termasuk tempat menginap. Tempat menginap ini diperlukan pula untuk melakukan pengamatan dan pengawasan terhadap daerah konservasi. Area yang memungkinkan untuk dibangun tempat menginap adalah zona buffering sebab di zona ini aktivitas para bekantan dan satwa masih sangat kurang bahkan tidak ada kecuali bagi bekantan atau satwa yang sedang dalam tahap rehabilitasi.

Titik zona buffering berada di area sekitar bawah Jembatan Barito memiliki wilayah lahan basah yang masih dapat dikembangkan. Area ini dapat dijadikan sebagai area penginapan bagi para peneliti sehingga para peneliti pun dapat merasakan langsung nuansa lahan basah di Kalimantan Selatan dan view kawasan konservasi yang dapat dilihat langsung dari area ini.

Dalam membangun nuansa lahan basah diperlukan hal-hal yang berkaitan ciri khas dengan lahan basah bagi kehidupan manusia. Ciri khas ini dapat berupa sirkulasi, bangunan, struktur konstruksi dan sebagainya. Beberapa contohnya adalah sirkulasi di lahan basah biasanya menggunakan titian, bangunan di lahan basah Kalimantan Selatan di dominasi oleh kayu atau bisa juga dengan bangunan lanting, dan untuk struktur konstruksi lahan basah di Kalimantan Selatan biasanya menggunakan kayu dengan model bangunan panggung.

Dengan demikian, hal yang dibutuhkan dalam Perancangan Stasiun Riset Bekantan pada Lahan Basah dapat berupa batasan aktivitas manusia masuk ke wilayah konservasi dan pengangkatan tema lahan basah pada desain bangunan agar dapat merasakan habitat asli dari para bekantan dan satwa liar di lahan basah. Dari ketiga titik kawasan tersebut masih belum direncanakan dengan matang dan belum ada desain yang memadai untuk para peneliti sehingga dengan adanya hal tersebut dapat mendukung kegiatan penelitian sekaligus edukasi bagi masyarakat tentang bekantan dan lahan basah sebagai habitat alaminya.

\section{Konsep Program}

Pada perancangan stasiun riset ini ada dua hal yang perlu diperhatikan dalam penelitian, yaitu peneliti dan objek yang diteliti. Dua hal ini berperan sebagai subjek dan objek. Seorang peneliti memerlukan kegiatan pengamatan objek dalam meneliti, sedangkan objek penelitian seperti bekantan memerlukan tingkat privasi yang lebih tinggi 
karena lebih mudah mengalami stres. Hal tersebut menyebabkan kesulitan bagi peneliti dalam melakukan pengamatan sehingga memerlukan solusi yang dapat mengatasi masalah tersebut agar penelitian dapat berjalan dengan baik.

Kondisi lingkungan kawasan penelitian juga menjadi hal penting karena merupakan kawasan yang dilindungi dan dijaga kelestariannya. Lingkungan kawasan penelitian tersebut memberi dampak bagi perlakuan bangunan yang akan dirancang untuk mendukung kegiatan penelitian di alam. Perlakuan bangunan tersebut dapat berupa penyediaan sirkulasi yang sesuai, bentuk bangunan yang dapat mengatasi iklim kawasan, dan sebagainya.

Dengan demikian, konsep program yang dapat diangkat pada Perancangan Stasiun Riset Bekantan pada Lahan Basah adalah konsep yang dapat menyelesaikan permasalahan rancangan secara fisik dan non-fisik agar kegiatan penelitian di kawasan dapat berjalan dengan baik. Dalam hal ini penulis mengajukan konsep subject-object interaction yang perwujudannya melalui konsep wetland ecology. Konsep subject-object interaction berperan dalam mengangkat tema interaksi antara subjek dan objek peneliti dengan peneliti sebagai pelaku atau subjek dapat merasakan langsung atau memahami kehidupan bekantan dan lahan basah. Konsep wetland ecology yang berperan dalam menampilkan ruang lingkup lahan basah dengan memasukan unsur alami ke bangunan untuk memperkuat identitas pada kawasan.

\section{PERMASALAHAN}

Berdasarkan latar belakang di atas permasalahan yang diangkat dalam perancangan tugas akhir stasiun riset bekantan pada lahan basah adalah bagaimana rancangan stasiun riset bekantan pada lahan basah yang selaras dengan kondisi alam sekitarnya sehingga dapat menjadi identitas kawasan tersebut.

\section{TINJAUAN PUSTAKA}

\section{A. Tinjauan Stasiun Riset Bekantan pada Lahan Basah}

Stasiun riset bekantan pada lahan basah dapat diartikan sebagai tempat pusat penelitian pembudidayaan dan pengembangan berupa kegiatan ilmiah berdasarkan data atau informasi untuk menyelesaikan permasalahan atau untuk mendapatkan pemahaman mengenai bekantan dan ruang lingkup lahan basah. Selain itu, stasiun riset tersebut juga mewadahi kegiatan untuk restorasi kawasan lahan basah serta ekowisata dengan minat khusus untuk edukasi.

\section{B. Tinjauan Bangunan Lahan Basah}

Indonesia beriklim tropis lembab sehingga di kawasan tersebut ketika musim hujan mengalami curah hujan yang lebat dan ketikan musim kemarau mengalami panas terik yang membuat elemen atap menjadi hal penting dalam bangunan pada kawasan tersebut. Arsitektur atap pada bangunan tradisional memiliki kemiringan atap yang besar, sedangkan untuk konsep pengudaraan berupa lubang ventilasi dengan jendela yang berkisi-kisi. Ventilasi tersebut berguna untuk mencegah panas dan mengatasi kelembaban di dalam ruangan. Hal tersebut disebabkan pengaruh tanah yang digenangi air ketika banjir atau pada bangunan di tepi sungai. Selain itu, lubang ventilasi dan jendela kisi-kisi menjadi pelengkap untuk memberi kenyaman di dalam ruangan.

Dengan demikian, bangunan panggung merupakan bentuk aplikasi dari lingkungannya di lahan basah. Bentuk panggung tersebut bertujuan agar bangunan tersebut tidak terendam ketika terjadi pasang naik. Bertahannya bangunan panggung pada lahan basah karena lahan basah menjadi sumber daya alam yang memiliki nilai besar, terutama kontribusinya bagi keanekaragaman hayati, penopang ekosistem, dan pengatur iklim secara makro. 


\section{Tinjauan Laboratorium}

Laboratorium adalah tempat yang dilengkapi dengan peralatan untuk mengadakan percobaan atau penelitian. Berdasarkan prinsipnya laboratorium mempunyai 3 fungsi dasar, yaitu laboratorium sebagai pusat pelayanan kegiatan penunjang akademik, laboratorium sebagai pusat pelayanan kegiatan penelitian dalam bidang tertentu, dan laboratorium sebagai pusat pelayanan publik. Selain itu laboratorium berperan penting juga dalam perguruan tinggi sebagai tempat kegiatan Tri Dharma Perguruan Tinggi, yaitu di bidang pendidikan dan pengajaran, penelitian dan pengabdian kepada masyarakat (Pascalis, 2018).

Secara umum salah satu standar peraturan dalam laboratorium adalah menjaga kebersihan dan predikat penelitian yang melindungi diri dan objek penelitiannya. Dalam hal tersebut secara arsitektural untuk menunjang kebersihan dapat dilakukan dengan meletakkan wastafel di dekat pintu masuk yang merupakan akses awal seorang peneliti yang penting. Selain itu, perbedaan layering ruang luar dan ruang dalam di laboratorium menjadi hal penting juga untuk menunjang batasan kebersihan lantai. Ada beberapa pertimbangan khusus menurut Triyono untuk mendesain sebuah laboratorium adalah sebagai berikut:

○ Gedung

Jenis gedung yang digunakan merupakan gedung yang terisolasi dan mengisolasi informasi yang diolah peneliti sebab penemuan tersebut dihasilkan dari sebuah isolasi sehingga menjadi tinjauan tertutup.

\section{- Tingkat biosafety}

Klasifikasi dalam tingkatan bahan kimia laboratorium dan hasil penelitian menjadi hal yang perlu diperhatikan. Tingkatan tersebut dapat membentuk tatanan bangunan yang menjadi penentu dari bangunan yang mudah tercemar hingga bangunan yang memerlukan perlakuan sosial.

- Aliran udara
Tingkat biosafety dapat menjadi penentu dalam perlakuan terhadap bukaan dan ventilasi.

- Teknologi yang digunakan

Klasifikasi jenis teknologi berdasarkan jenis laboratorium, jenis aktivitas, dan objek penelitian sehingga teknologi yang paling canggih dengan kebutuhan energi yang besar akan diletakkan lebih dekat dengan sumber energi.

- Sumber daya manusia

Tingkatan klasifikasi objek penelitian yang dikaji dari hal yang umum hingga hal yang mikro sehingga sumber daya dapat mempengaruhi sirkulasi antar ruang dan antar laboratorium serta penunjangnya.

\section{Tinjauan Konsep}

a. Konsep Konservasi, Restorasi, dan

\section{Ekowisata}

Konservasi merupakan upaya manusia untuk melindungi dan melestarikan alam. Konservasi tersebut mencakup pula dalam upaya efisiensi, produksi, transmisi, dan distribusi energi agar mengalami pengurangan konsumsi energi tersebut. Hal tersebut membuat pengelolaan kuantitas tertentu dapat stabil yang berdampak pula pada keanekaragaman genetik dari spesies dapat dipertahankan dengan lingkungan alaminya (Christanto, 2014).

Kawasan konservasi memiliki beberapa karakteristik diantaranya adalah:

- Keaslian atau keunikan dari karakteristik ekosistem.

- Tempat tinggal atau habitat bagi spesies-spesies yang endemik, langka, terancam punah, atau jenis-jenis yang dilindungi perundang-undangan.

- Wadah yang mempunyai keanekaragaman plasma nutfah yang alami.

- Bentang alam atau ciri geofisika yang bernilai estetik/saintifik

- Perlindungan hidro-orologi.

- Wisata alam yang alami.

b. Metabolisme-Organik

Arsitektur metabolisme-organik merupakan sebuah cara untuk 
menyelesaikan masalah dalam arsitektur dengan kondisi alam sekitarnya. Hal tersebut melalui pendekatan arsitektur metabolisme dengan metode arsitektur organik. Metabolisme-organik tersebut memiliki kesamaan dalam hubungannya dengan alam sekitar objek arsitekturnya.

Pendekatan arsitektur metabolisme merupakan desain arsitektur yang menunjukan kemampuan bertahan hidup manusia. Gerakan metabolisme dimulai dari konferensi desain di dunia bersama deklarasinya, Metabolism 1960 "A Proposal for a new Urbanism" dengan tokoh-tokoh yang tergabung adalah Kiyonori Kikutake, Fumihiko Maki, Masato Otaka, Kisho Korukawa dan Kiyoshi Awazu (desainer grafis). Ada 2 hal yang menyebabkan deklarasi tersebut menjadi penting, yaitu:

- Menggambarkan perasaan bahwa manusia sebaiknya dipandang sebagai entitas perputaran alam.

- Menggambarkan kepercayaan bahwa teknologi merupakan pelengkap dari kehidupan manusia.

Arsitektur organik adalah arsitektur yang mengadopsi keselarasan alam dengan tempat tinggal manusia melalui keharmonisan desain dan tapak bangunan termasuk bagian ruang dalamnya. David Pearson adalah seorang ahli teori yang memberikan usulan terhadap aturan organisasi perancangan arsitektur organik yang disebut dengan Piagam Gaia. Piagam tersebut berisi:

- Diilhami dari alam

- Memberikan desain apa adanya

- Mengikuti arus dan menyesuaikan diri

- Mencukupi kebutuhan sosial, fisik dan rohani.

- Tumbuh keluar dan unik

- Menandai jiwa muda dan kesenangan

- Mengikuti irama

Berdasarkan artikel What is Organic Architecture Ganguly (2008) arsitektur organik adalah kehidupan dari hasil sebuah perasaan, seperti cinta, kegembiraan, keindahan, harmoni, persaudaraan, dan kebebasan. Arsitektur organik memiliki integrasi dengan tapak sehingga menjadi satu kesatuan dalam komposisi yang saling berkaitan antara bangunan dan lingkungan sekitarnya. Dengan kata lain arsitektur organik tersebut berperan dalam keharmonisan antara ruang luar dan ruang dalam (Ganguly, 2008).

\section{PEMBAHASAN}

\section{A. Lokasi}

a. Pemilihan Tapak dan Lokasi

Pemilihan tapak menjadi salah satu faktor penting dalam Perancangan Stasiun Riset Bekantan pada Lahan Basah. Tapak yang dipilih harus sesuai dengan kondisi lahan basah dan berdekatan dengan habitat bekantan. Selain itu, jika ingin menjadikan Stasiun Riset Bekantan pada Lahan Basah menjadi identitas kawasan maka tapak yang dipilih merupakan tapak yang disekitarnya sudah memiliki atau sudah menjadi penanda untuk daerah sekitarnya. Hal tersebut dilakukan agar bangunan stasiun riset dapat menjadi bagian dari penanda kawasan tersebut.

Tapak yang dipilih pada Perancangan Stasiun Riset Bekantan pada Lahan Basah ini berada di sekitar Kawasan Jembatan Barito. Di kawasan tersebut ada dua pulau yang dilindungi yaitu Pulau Bakut dan Pulau Curiak. Kedua pulau tersebut merupakan wilayah dilindungi atau dikonservasi sehingga perlakuan pada tapak pada stasiun riset tersebut akan berbeda dari umumnya. Dalam hal ini pada Pulau Curiak menjadi lokasi utama dibandingkan Pulau Bakut karena pada Pulau Bakut telah menjadi taman wisata alam yang dijalankan oleh pemerintah sehingga aktivitas manusia sedikit lebih dominan dibandingkan di Pulau Curiak.

\section{b. Tinjauan Umum Lokasi}

Stasiun riset bekantan pada lahan basah berada di kawasan sekitar Jembatan Barito, Kalimantan Selatan yang secara geografis terletak di sekitar 114'32' BT 114'34' BT dan $3^{\circ} 12^{\prime}$ LS - 3'14' LS. Kawasan tersebut memiliki tapak dengan potensi alam habitat asli bekantan dan lahan basah. Kawasan ini berada di Sungai Barito dengan Pulau Bakut yang berada di bawah Jembatan Barito dan tidak jauh dari Pulau 
Bakut terdapat Pulau Curiak. Pulau Bakut adalah wilayah yang dikonservasi secara resmi oleh pemerintah sedangkan Pulau Curiak adalah kawasan yang dilindungi dan dikelola oleh $\mathrm{SBI}$ yang bekerja sama dengan ULM.

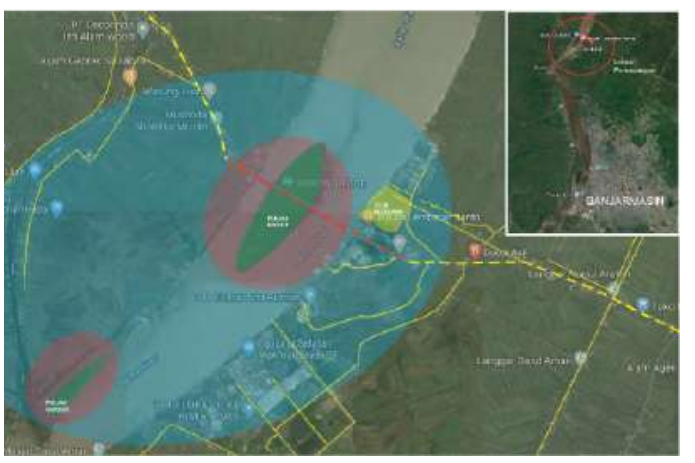

Gambar 2. Lokasi kawasan perancangan Sumber: penulis 2020

c. Kondisi dan Luasan Tapak

Kawasan sekitar Jembatan Barito berupa lahan basah. Di Pulau Bakut dan Pulau Curiak masih belum memiliki jaringan utilitas seperti listrik ataupun air bersih. Kawasan tersebut didominasi oleh vegetasi-vegetasi lahan basah seperti pohon rambai yaitu, makanan bagi para bekantan dan satwa lain,

Luas total kawasan perancangan stasiun riset bekantan pada lahan basah adalah sekitar 630 ha dengan 3 titik lokasi perancangan, yaitu di sekitar kawasan bawah Jembatan Barito, di Pulau Bakut, dan di dekat Pulau Curiak. Luas titik sekitar kawasan Jembatan Barito 0,7 ha, di Pulau Bakut 1,5 ha, dan di dekat Pulau Curiak 0,5 ha yang sudah memiliki stasiun riset bekantan sederhana. Berikut adalah gambaran kondisi tapak:
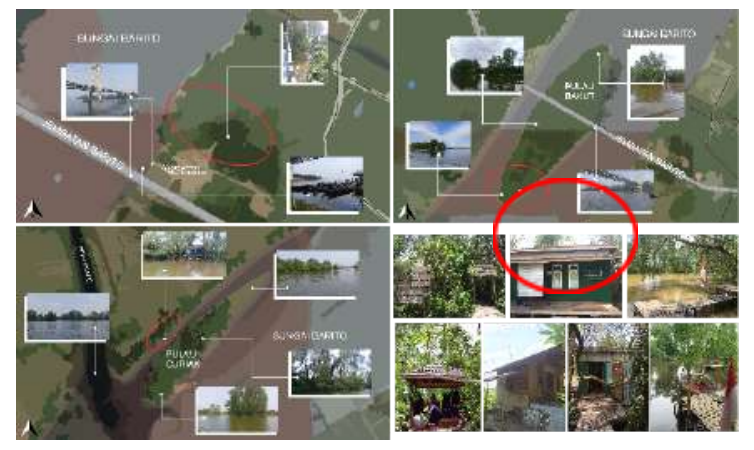

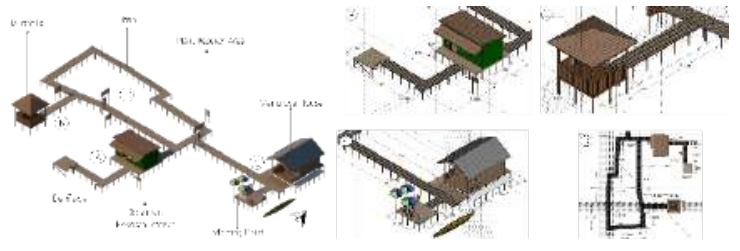

Gambar 3. Data eksisting kawasan Sumber: Penulis 2020

\section{B. Konsep Programatik}

Berdasarkan permasalahan arsitektural yang diajukan sebelumnya, yaitu bagaimana rancangan stasiun riset bekantan pada lahan basah yang selaras dengan kondisi alam sekitar sehingga dapat menjadi identitas kawasan tersebut, maka konsep yang diterapkan adalah konsep "wetland ecology" yang di dalamnya meliputi "subject-object interaction".

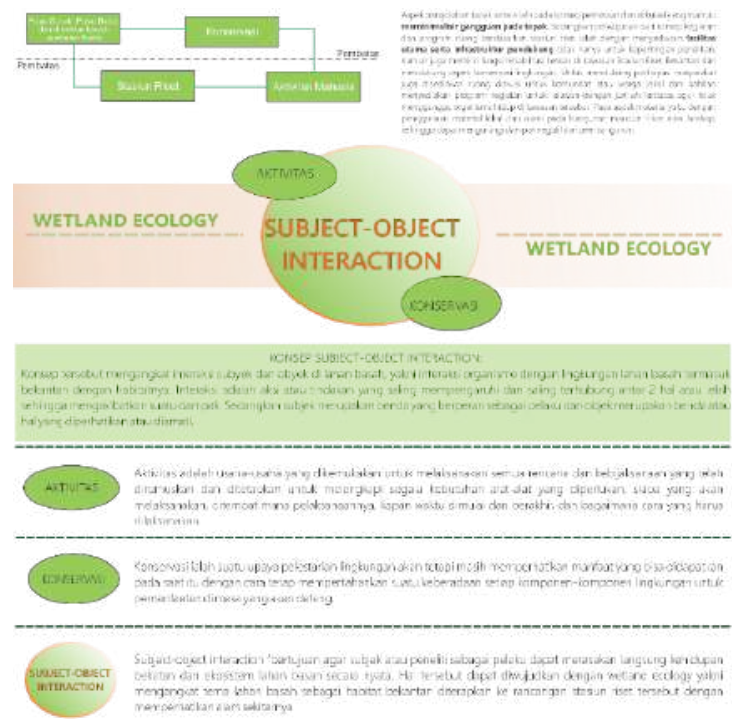

Gambar 4. Konsep programatik Stasiun Riset Bekantan pada Lahan Basah

Sumber: Penulis 2020

Perancangan stasiun riset ini dibagi menjadi 2 kepentingan, yaitu subjek dan objek. Subjek adalah pelaku atau pengguna di dalam perancangan tersebut sedangkan objek adalah ekosistem lahan basah itu sendiri baik dari satwa liarnya maupun vegetasinya. Pelaku dalam stasiun riset ini difokuskan pada peneliti karena 
Perancangan Stasiun Riset Bekantan pada Lahan Basah ini ditujukan untuk kegiatan penelitian. Objek dalam stasiun riset ini berupa sesuatu yang diteliti oleh peneliti itu sendiri seperti bekantan, mangrove dan lahan basah. Subjek dan objek ini memiliki perlakuan yang berbeda sesuai dengan kebutuhannya namun masih tetap saling terkait satu sama lainnya.

Subjek dari stasiun riset ini memerlukan objek untuk melakukan berbagai penelitian dan objek juga memerlukan subjek agar tetap lestari serta terawat. Hal tersebut merupakan hubungan timbal balik yang menguntungkan untuk pelestarian ekosistem lahan basah termasuk di dalamnya bekantan. Bekantan dan lahan basah merupakan hewan dan ekosistem endemik dari Kalimantan Selatan sekaligus identitas daerah.

Lokasi atau tapak memiliki pengaruh penting terhadap perancangan stasiun riset. Aspek pengolahan tapak yang perlu dipertimbangkan antara lain pada konsep penzonaan dan sirkulasi mampu meminimalkan gangguan pada tapak. Perwujudan dari konsep kegiatan dan program ruang berdasarkan stasiun riset adalah dengan menyediakan fasilitas utama penelitian serta infrastruktur pendukung, tidak hanya untuk kepentingan penelitian, namun juga memiliki fungsi rehabilitasi hewan di daerah tersebut dan mendukung aspek konservasi lingkungan. Sebagai pendukung partisipasi masyarakat juga disediakan ruang diskusi untuk komunitas atau warga lokal dan menyediakan program kegiatan untuk relawan dengan jumlah terbatas agar tidak mengganggu organisme hidup di wilayah inti yaitu Pulau Bakut dan Pulau Curiak. Pada aspek material yaitu dengan penggunaan material lokal dan alami pada bangunan maupun titian area lanskap, sehingga dapat mengurangi dampak negatif dari pembangunan.
Dengan demikian konsep yang dapat diangkat pada Perancangan Stasiun Riset Bekantan pada Lahan Basah adalah "subject-object interaction". Konsep tersebut mengangkat interaksi subjek dan objek di lahan basah, yaitu interaksi organisme dengan lingkungan lahan basah termasuk bekantan dengan habitatnya. Interaksi adalah aksi atau tindakan yang saling mempengaruhi dan saling terhubung antar 2 hal atau lebih sehingga mengakibatkan suatu dampak, sedangkan subjek merupakan benda yang berperan sebagai pelaku dan objek merupakan benda atau hal yang diperhatikan atau diamati. "Subject-object interaction" bertujuan agar subjek atau peneliti sebagai pelaku dapat merasakan langsung kehidupan bekantan dan ekosistem lahan basah secara nyata. Hal tersebut dapat diwujudkan dengan "wetland ecology" yaitu mengangkat tema ruang lingkup lahan basah sebagai habitat bekantan yang diterapkan ke rancangan stasiun riset tersebut dengan memperhatikan unsur alam di sekitar bangunannya. Memasukan unsur alam bangunan ini berfungsi untuk memperkuat identitas kawasan.

\section{Konsep Rancangan}

Sebagai perwujudan nyata konsep "wetland ecology and subject-object interaction" yang dipengaruhi oleh metode metabolisme-organik, maka konsep program di atas diwujudkan ke dalam dua aspek, yaitu aspek fisik dan aspek non-fisik. Konsep "wetland ecology" sebagai perwujudan aspek fisik dan konsep "subject-object interaction" sebagai perwujudan non-fisik. Aspek fisik meliputi bentuk bangunan, sirkulasi di kawasan, dan material yang digunakan, sedangkan aspek non-fisik meliputi pembagian zona dalam kawasan konservasi, penyamaran atau kamuflase bangunan terhadap lingkungan sekitar, dan 
sistem berkesinambungan bangunan pada kawasan. Aspek fisik dan non-fisik tersebut menjadi unsur utama dalam konsep rancangan dan berdasarkan analisis penulis sebagai aspek pelengkap konsep warna dan konsep tatanan massa bangunan yang mempengaruhi stasiun riset juga diterapkan.

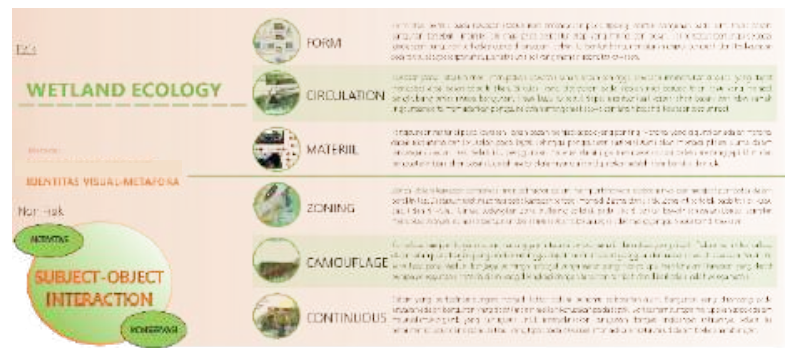

Gambar 5. Konsep rancangan Stasiun Riset Bekantan pada Lahan Basah

Sumber: Penulis 2020

\section{a. Konsep Zoning}

Stasiun Riset Bekantan pada Lahan Basah berada pada kawasan konservasi. Wilayah yang dikonservasi berada di Pulau Bakut, sedangkan Pulau Curiak merupakan kawasan yang dilindungi. Hal ini menyebabkan stasiun riset memiliki dua zona kawasan untuk mempertahankan keberadaannya. Dua zona tersebut adalah zona inti dan zona buffering (penyangga) dimana zona inti meliputi Pulau Bakut dan Pulau Curiak serta zona penyangga di sekitar bawah Jembatan Barito. Zona inti merupakan zona yang dilindungi sedangkan zona penyangga merupakan zona yang melindungi kawasan inti agar keberadaan kawasan konservasi dapat mempertahankan eksistensinya. Selain itu, zonasi pada kawasan stasiun riset saling ketergantungan satu dengan yang lainnya. Jika terjadi kerusakan pada zona penyangga, maka zona inti akan terancam keberadaannya. Artinya konsep zoning ini merupakan sistem metabolisme dalam kawasan, yaitu vitalitas kawasan konservasi atau kemampuan zona inti agar tetap lestari dan bertahan.

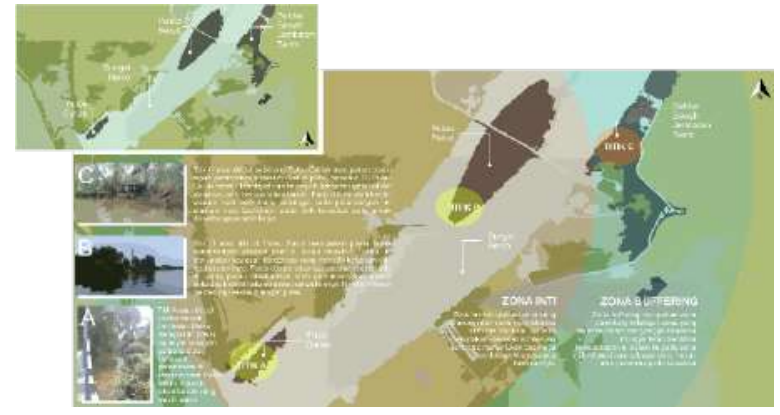

Gambar 6. Konsep zoning

Sumber: Penulis 2020

\section{b. Konsep Form}

Konsep bentuk bangunan Stasiun Riset Bekantan pada Lahan Basah mengacu pada bentuk arsitektur tropis basah sehingga bangunan lebih mengutamakan atap atau bagian kepala bangunan dibandingkan dinding atau badan bangunan. Hal ini dipilih sebagai tanggapan bangunan terhadap iklim di kawasan tersebut.

Massa bangunan yang berada pada kawasan memiliki bentuk dasar segitiga dan persegi atau pola garis-garis. Bentuk segitiga dipilih sebagai bentuk ideal atap pada kawasan, sedangkan persegi atau garis-garis dipilih sebagai bentuk yang paling efisien untuk mewadahi laboratorium penelitian. Selain itu, bentuk segitiga dan pola garis ini merupakan metafora dari bentuk alam, yaitu segitiga berasal dari bentuk ujung daun rambai (daun rambai salah satu makanan bekantan) dan pola garis atau persegi berasal dari tanaman lahan basah yang akar-akarnya muncul ke permukaan menyerupai batas habitat para bekantan atau satwa lainnya.

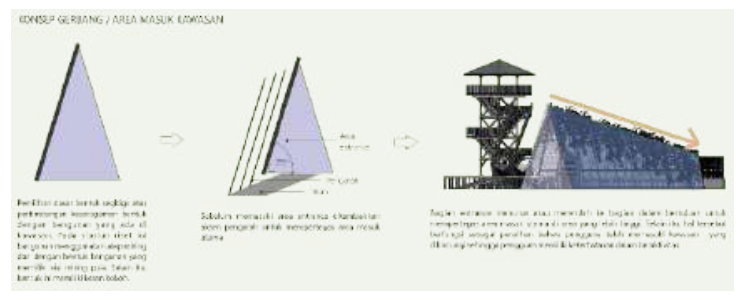




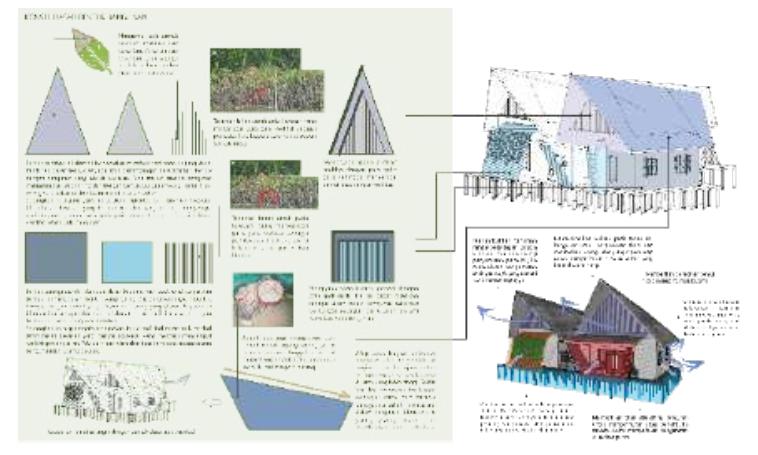

Gambar 7. Konsep form

(Sumber: Penulis 2020)

Pada bagian gerbang kawasan bentuk dasar yang diambil adalah bentuk segitiga dengan bagian samping menyerupai trapesium. Segitiga pada bagian gerbang ini dipilih untuk menyesuaikan keseragaman bentuk pada massa bangunan di kawasan. Bangunan di kawasan memiliki atap miring sehingga untuk menyesuaikannya pada bagian gerbang menggunakan bentuk dasar segitiga. Sebelum memasuki gerbang pada bagian sisi samping titian diberi garis atau tiang-tiang pengarah yang juga berfungsi untuk mempertegas pintu masuk utama kawasan. Pada bagain lorong gerbang juga diberi penekanan dengan menurunkan atau merendahkan bagian ujung lorong. Hal tersebut dapat memberikan kesan bagi pengunjung ataupun peneliti bahwa mereka telah memasuki kawasan dengan aktivitas yang dibatasi.

Pada bangunan di kawasan bentuk dasar yang diambil adalah bentuk segitiga dan persegi atau pola garis-garis. Segitiga pada bagian kepala bangunan dan persegi atau pola garis-garis pada bagian badan bangunan. Selain itu, pada bagian atap bangunan juga mengadopsi dari bentuk atap rumah anjung surung (salah satu rumah tradisional banjar) sebagai penguat identitas daerah kawasan.

Bentuk bangunan stasiun riset mempertimbangkan kondisi iklim sehingga pada bagian badan bangunan memiliki banyak bukaan untuk memberikan sirkulasi udara alami. Selain sebagai sirkulasi alami, dengan banyaknya bukaan juga memberi kesempatan kepada para pengguna bangunan merasakan langsung suasana lahan basah dan bukaan yang lebar tersebut adalah ciri khas dari bangunan iklim tropis basah. Pola garis pada bangunan berperan sebagai aksen bangunan dan sebagai wadah kamuflase para pengamat atau peneliti.

\section{c. Konsep Circulation}

Sirkulasi pada tiga titik rancangan stasiun riset mengikuti alur pada lingkungan alam. Sirkulasi pada kawasan tersebut dibentuk dengan titian yang memanjang mengikuti alur vegetasi lahan basah sekitarnya. Titian pada stasiun riset ini memiliki struktur panggung dengan bagian sisi samping titian diberi pengaman atau pagar sehingga titian yang dibuat dengan kayu ini lebih aman ketika digunakan. Selain itu, titian ini juga menjadi identitas sirkulasi pada lahan basah karena dengan menggunakan titian panggung dapat meminimalkan kerusakan alam di kawasan tersebut. Dengan demikian, massa bangunan pada stasiun riset ini dihubungkan oleh titian kayu antar bangunannya dan dapat memperkuat kesan ruang lahan basah alami bagi para peneliti atau penggunanya

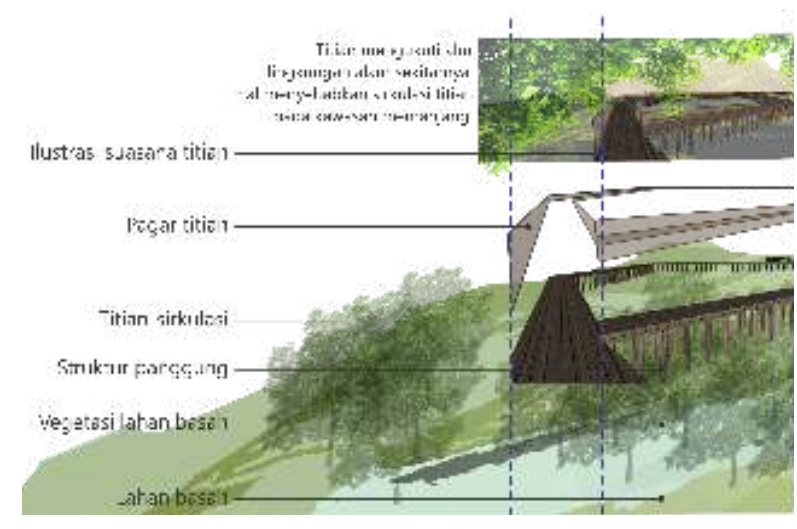

Gambar 2 Konsep circulation

(Sumber: Penulis 2020) 


\section{d. Konsep Materiil}

Material yang digunakan pada stasiun riset berupa material-material alami. Material alami ini bertujuan untuk meminimalkan kerusakan pada lahan basah karena dampak pembangunan. Penggunaan material alami ini juga dapat membantu para peneliti dalam mengetahui ketahanan berbagai jenis material yang dapat bertahan di lahan basah. Material tersebut berupa kayu ulin, kayu jati, kayu sonokeling, bambu, serabut/ijuk dan sebagainya.

Pada bagian kepala bangunan atau atap di stasiun riset menggunakan material serabut ijuk, badan bangunan menggunakan kayu jati, sedangkan bagian struktur seperti kolom dan balok menggunakan kayu ulin. Material-material tersebut dipilih berdasarkan ketahanan mereka terhadap kondisi lahan basah, seperti kayu ulin yang cocok untuk struktur panggung, kayu jadi yang tahan terhadap rayap, dan sebagainya.

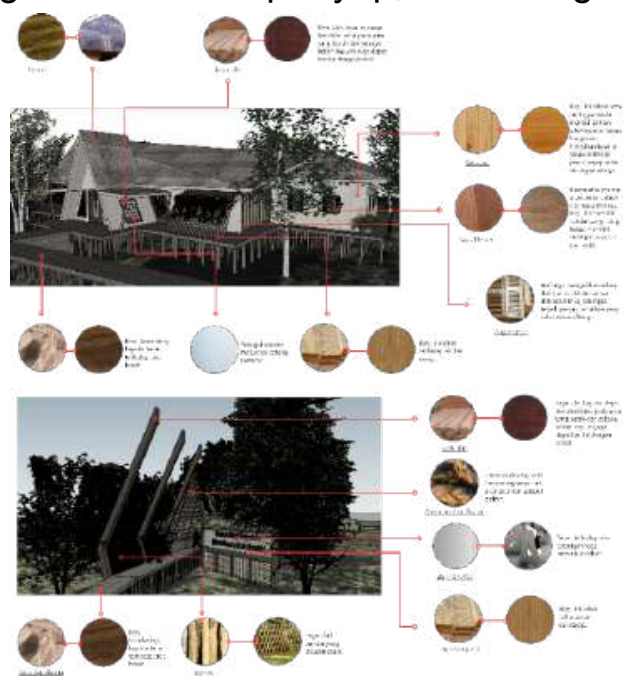

Gambar 3. Konsep materiil Sumber: Penulis 2020

\section{e. Konsep Camouflage}

Konsep kamuflase pada stasiun riset berperan dalam menyamarkan keberadaan manusia yang sedang mengamati bekantan dan habitatnya di lahan basah secara langsung. Dinding kamuflase ini berada pada bagian pembatas antara kehidupan alami bekantan dan titik lokasi tapak stasiun riset. Pada bagian dinding tersebut diberi tanaman merambat atau tanaman gantung. Tujuan dari tanaman ini sebagai pendukung penyamaran dari dinding berlubang sehingga dinding pengamatan tersebut menyerupai semak-belukar. Selain itu, penggunaan warna alami juga memperkuat penyamaran stasiun riset menyerupai bagian dari alam, seperti warna coklat kehitaman yang digunakan pada dinding dan warna hijau dari tanaman rambat.

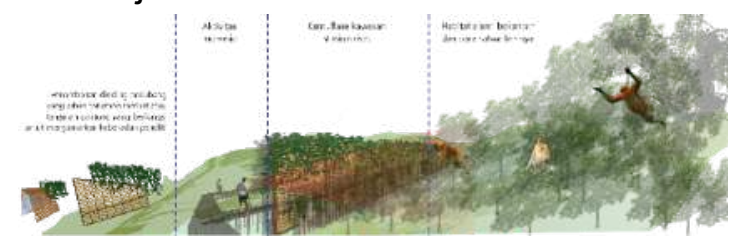

Gambar 4. Konsep camouflage (Sumber: Penulis 2020)

\section{f. Konsep Continuous}

Kawasan stasiun riset menggunakan sistem utilitas mandiri. Hal ini bertujuan untuk menghemat energi dan meminimalkan kerusakan pada lingkungan alam sekitar bangunan, seperti penggunaan panel surya dan septictank biofilter. Panel surya diletakkan pada bagian atap bangunan yang pada sisi paling tinggi. Hal tersebut bertujuan untuk memaksimalkan sinar matahari yang didapat, sedangkan septictank biofilter ini bertujuan untuk mengolah limbah yang dihasilkan oleh aktivitas manusia agar limbah tersebut tidak mencemari tanah di kawasan. Selain itu, penggunaan struktur pondasi kacapuri juga bertujuan untuk mengurangi dampak kerusakan tanah pada lahan basah.

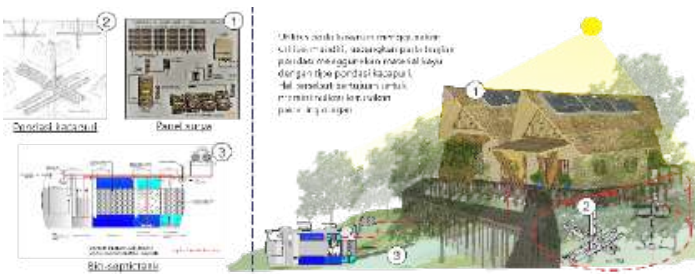

Gambar 5. Konsep continuous (Sumber: Penulis 2020) 


\section{g. Konsep Warna}

Konsep warna pada stasiun riset menggunakan warna-warna alami sebagai warna dominan. Hal tersebut bertujuan untuk menyelaraskan bangunan dengan alam sekitarnya sehingga dapat menyatu dan menjadi bagian dari lingkungannya. Selain itu, penggunaan warna alami tersebut juga berperan dalam konsep kamuflase agar subjek dan objek penelitian dapat berinteraksi secara tidak langsung dan dapat berjalan baik tanpa objek penelitian merasa terganggu.

Warna netral diperlukan pada stasiun riset. Warna ini dapat berfungsi untuk menyeimbangkan warna lain yang diperlukan dan tidak termasuk warna-warna alami agar mencapai kondisi warna yang selaras atau harmonis.

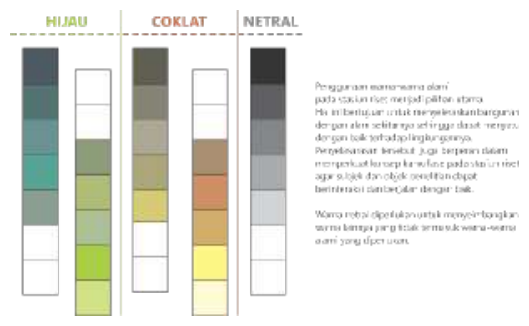

Gambar 6. Konsep warna

(Sumber: Penulis 2020)

h. Konsep Tatanan Massa Bangunan

Konsep tatanan massa pada kawasan stasiun riset menyesuaikan bentuk tapak dengan perletakan massa bangunan berdasarkan kebutuhan dan fungsi bangunan masing-masing. Pada stasiun riset di sekitar bawah Jembatan Barito berperan sebagai area penerima dan pusat rehabilitasi bekantan maupun satwa lainnya. Kawasan stasiun riset ini menyesuaikan lingkungan sekitarnya dengan sirkulasi yang mengikuti alur anak sungai kecil dari Sungai Barito. Area parkir kendaraan darat diletakkan pada bagian yang memiliki vegetasi minim dengan posisi yang paling dekat dari jalan utama. Laboratorium mangrove diletakkan pada bagian yang memiliki vegetasi minim akibat adanya bagian tanah yang diurug sebelumnya. Hal tersebut bertujuan untuk memicu aktivitas menghijaukan kembali pada area tersebut dan mengembalikan lingkungan sekitar menjadi alami seperti semula, sedangkan penangkaran bekantan diletakkan pada posisi yang paling jauh dari jalan utama sehingga terletak pada bagian paling belakang kawasan yang merupakan hutan lahan basah.

Pada kawasan stasiun riset di Pulau Bakut diletakkan pada bagian ujung kawasan yang bertujuan untuk meminimalkan gangguan pada bagian tengah dan tepi pulau yang didominasi oleh habitat bekantan. Sirkulasi kawasan pada pulau ini memanjang dari sisi tenggara ke sisi barat laut pulau dengan memperhatikan lingkungan asli kawasan agar aktivitas peneliti dapat menyebar dan merasakan langsung suasana lahan basah. Selain itu, titian untuk sirkulasi kawasan juga menyebar ke bagian depan dan belakang kawasan agar memudahkan pengamatan terhadap lahan basah dan satwa disekitarnya, sedangkan perletakan massa bangunan utama seperti laboratorium diletakkan pada posisi yang lurus untuk memusatkan aktivitas inti dalam satu titik sehingga meminimalkan gangguan pada area pengamatan.

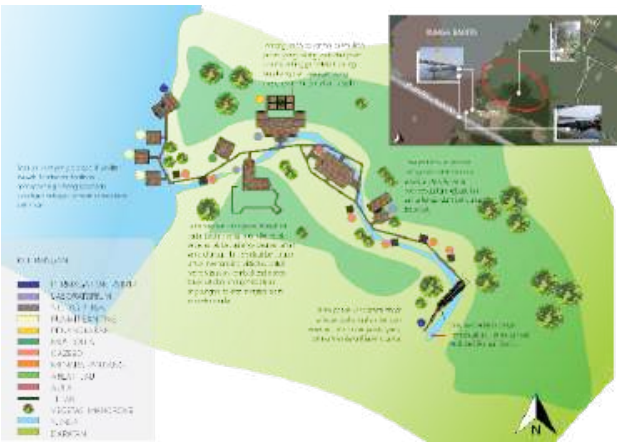

Gambar 7. Konsep tatanan massa sekitar bawah Jembatan Barito

(Sumber: Penulis 2020) 


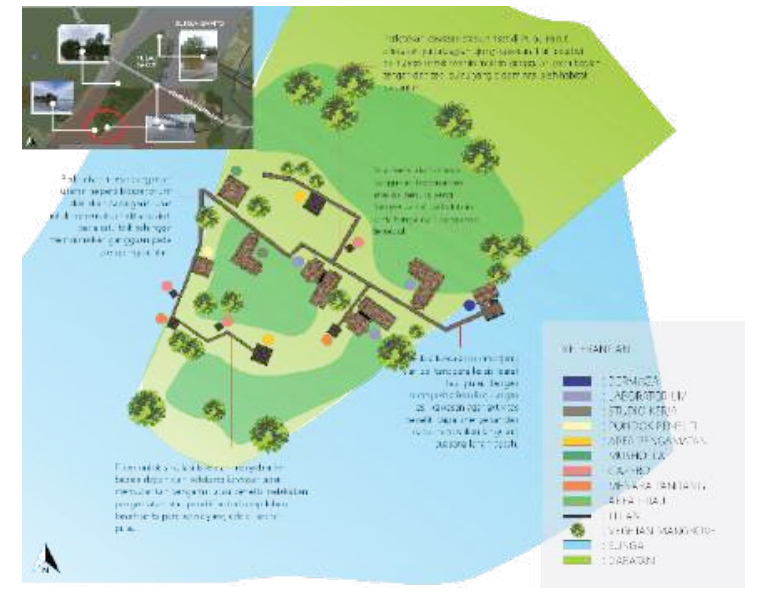

Gambar 8. Konsep tatanan massa di Pulau Bakut

(Sumber: Penulis 2020)

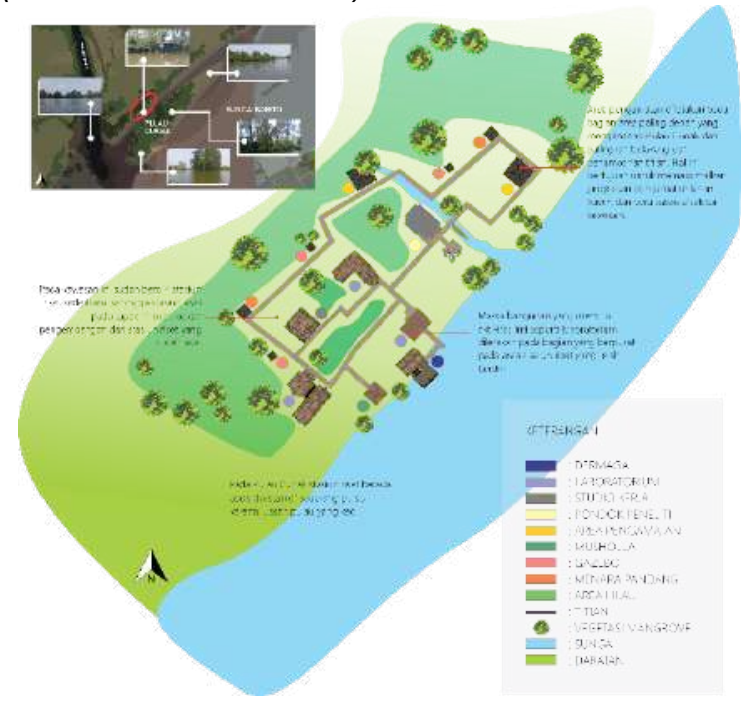

Gambar 9. Konsep tatanan massa di Pulau Curiak

(Sumber: Penulis 2020)

Pada kawasan stasiun riset di Pulau Curiak terletak di seberang pulau karena luasan pulau yang kecil. Kawasan ini sudah ada berdiri stasiun riset sederhana sehingga stasiun riset pada tapak ini merupakan pengembangan dari stasiun riset yang sudah ada. Massa bangunan yang memiliki aktivitas inti seperti laboratorium diletakkan pada bagian yang berpusat pada area stasiun riset yang telah berdiri, sedangkan area pengamatan diletakkan pada bagian paling depan yang menghadap Pulau Curiak dan paling belakang dari penambahan titian.
Hal ini bertujuan untuk memaksimalkan jangkauan pengamatan lahan basah dan para satwa di sekitarnya termasuk bekantan.

\section{HASIL}

\section{A. Site Plan Kawasan Stasiun Riset Bekantan pada Lahan Basah}

Berdasarkan hasil analisis dan konsep yang diajukan oleh Penulis, rancangan awal site plan pada kawasan terbagi menjadi titik lokasi stasiun riset. Tiga titik lokasi kawasan stasiun riset menyesuaikan zonasi konservasi yang terdiri dari zona inti dan zona buffering untuk menjaga dan melestarikan bekantan beserta habitat alaminya. Site plan zona buffering berada di sekitar bawah Jembatan Barito, zona inti di Pulau Bakut berada di bagian barat daya pulau, sedangkan zona inti di Pulau Curiak berada di bagian daratan yang berseberangan dengan pulau tersebut karena luasan Pulau Curiak yang kecil.

Sirkulasi pada kawasan menggunakan sirkulasi dengan menyesuaikan kondisi alam sekitarnya sehingga penataan massa bangunan mengikuti sirkulasi untuk meminimalkan dampak kerusakan pada lingkungan. Selain itu, dari site plan juga dapat terlihat konsep-konsep rancangan yang diterapkan pada kawasan. Konsep tersebut mencakup aspek fisik, dan non-fisik serta aspek pelengkap yang mempengaruhi tiga kawasan stasiun riset.

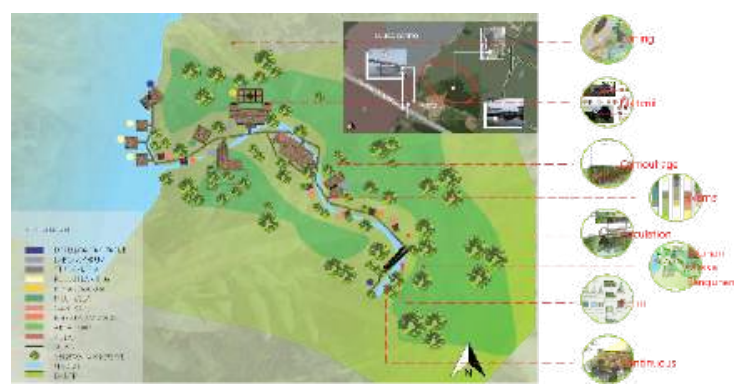

Gambar 10. Site plan kawasan stasiun riset di sekitar bawah Jembatan Barito

(Sumber: Penulis 2020) 


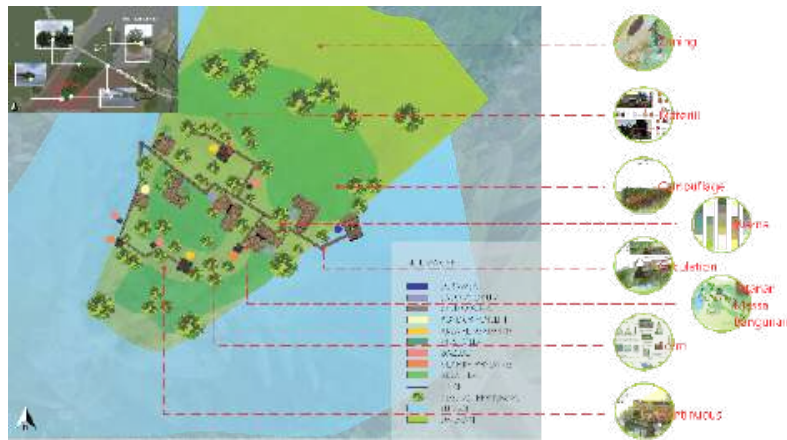

Gambar 11. Site plan kawasan stasiun riset di Pulau Bakut

(Sumber: Penulis 2020)

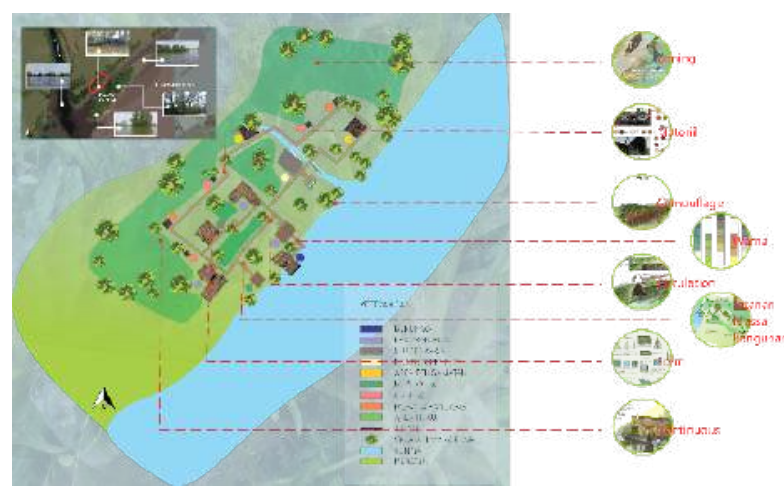

Gambar 12. Site plan kawasan stasiun riset di Pulau Curiak

(Sumber: Penulis 2020)

\section{B. Eksterior Bangunan di Kawasan Stasiun Riset Bekantan pada Lahan Basah}

Berdasarkan hasil analisis dan konsep yang diajukan Penulis, eksterior bangunan pada kawasan stasiun riset dirancang dengan menyelaraskan lingkungan sekitar bangunan yang merupakan hutan lahan basah dengan habitat bekantan di dalamnya. Hal ini juga bertujuan agar stasiun riset tersebut menjadi identitas kawasan dengan rancangan bentuk yang dapat menonjolkan ciri khas lahan basah. Rancangan eksterior bangunan di kawasan dapat dilihat pada gambar-gambar berikut:

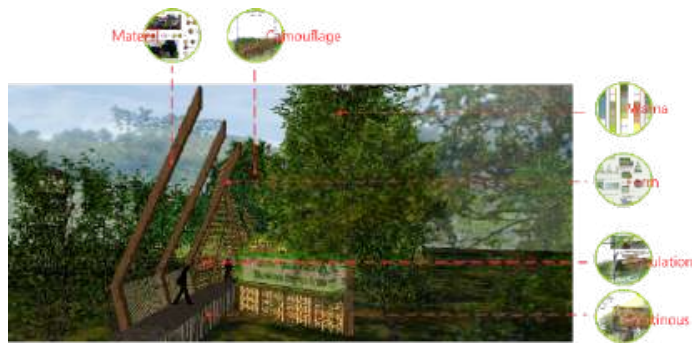

Gambar 13. Ilustrasi pintu masuk kawasan dan penerapan konsep

(Sumber: Penulis 2020)

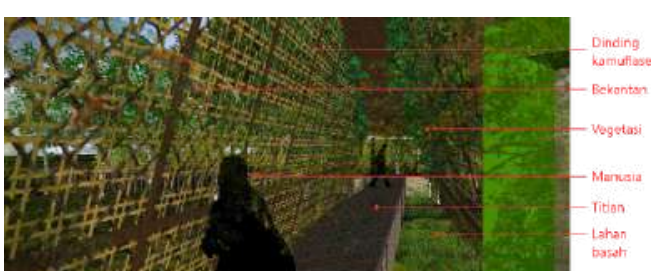

Gambar 14. Ilustrasi kamuflase untuk objek penelitian

(Sumber: Penulis 2020)

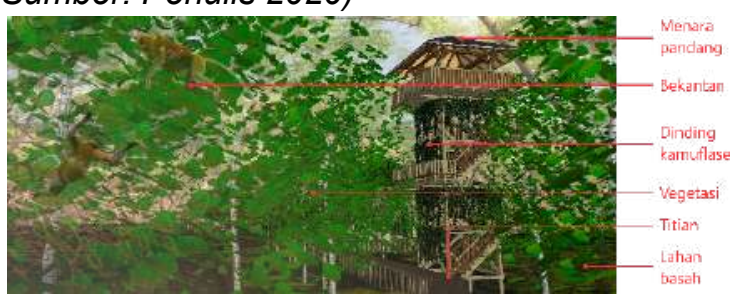

Gambar 15. Ilustrasi menara pengamatan

(Sumber: Penulis 2020)

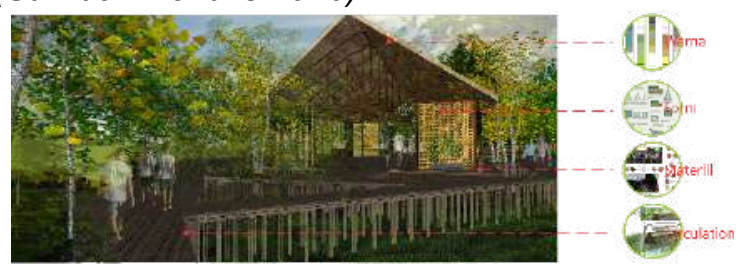

Gambar 16. Ilustrasi bangunan aula dan penerapan konsep

(Sumber: Penulis 2020)

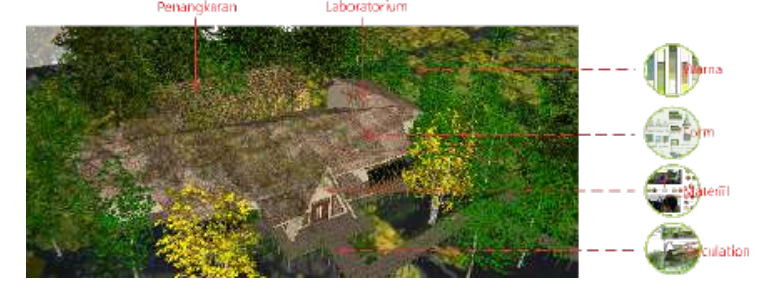

Gambar 17. Ilustrasi bangunan laboratorium bekantan dan penangkaran

(Sumber: Penulis 2020) 


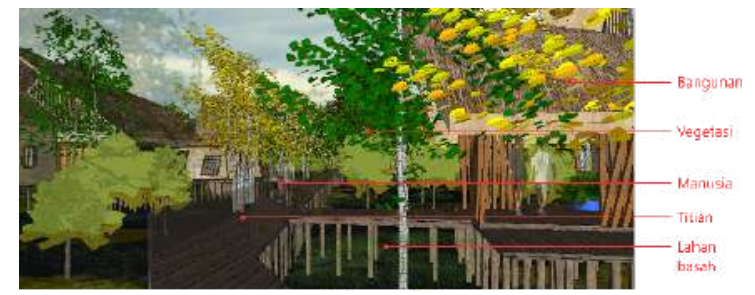

Gambar 18. Ilustrasi suasana dalam kawasan (Sumber: Penulis 2020)

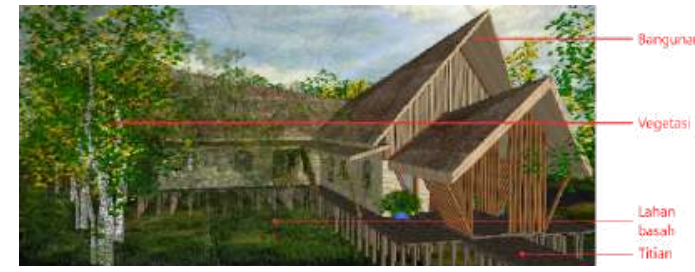

Gambar 19. Ilustrasi bangunan laboratorium mangrove

(Sumber: Penulis 2020)

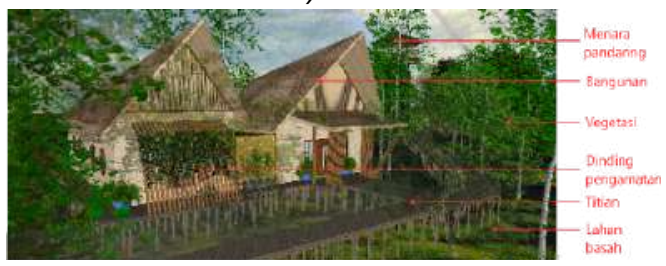

Gambar 20. Ilustrasi bangunan laboratorium lahan basah

(Sumber: Penulis 2020)

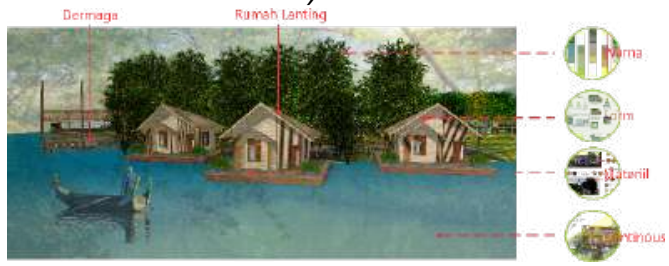

Gambar 21. Ilustrasi bangunan rumah lanting dan penerapan konsep

(Sumber: Penulis 2020)

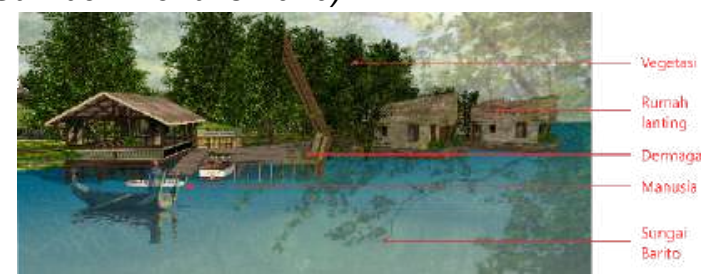

Gambar 22. Ilustrasi dermaga di kawasan

(Sumber: Penulis 2020)

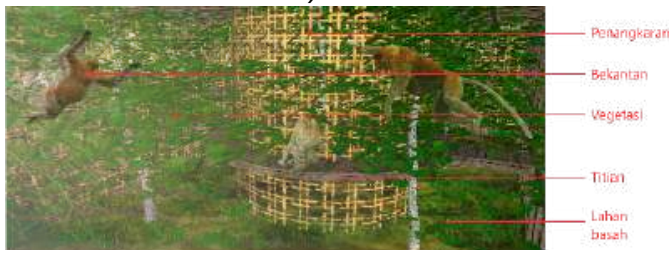

Gambar 23. Ilustrasi penangkaran

(Sumber: Penulis 2020)

\section{Interior Bangunan Laboratorium dan Klinik Satwa}

Interior bangunan didominasi oleh perabot laboratorium. Perabot laboratorium memiliki standar bentuk dan dimensi tertentu sehingga bentuk ruangan pada bangunan stasiun riset didominasi oleh bentuk persegi yang menyesuaikan dimensi perabot tersebut. Interior bangunan di stasiun riset dapat dilihat pada gambar-gambar berikut:

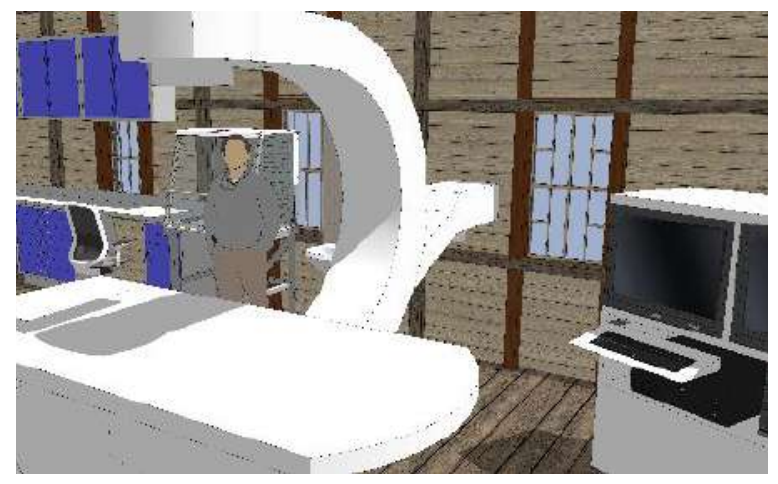

Gambar 24. Ilustrasi interior klinik hewan (Sumber: Penulis 2020)

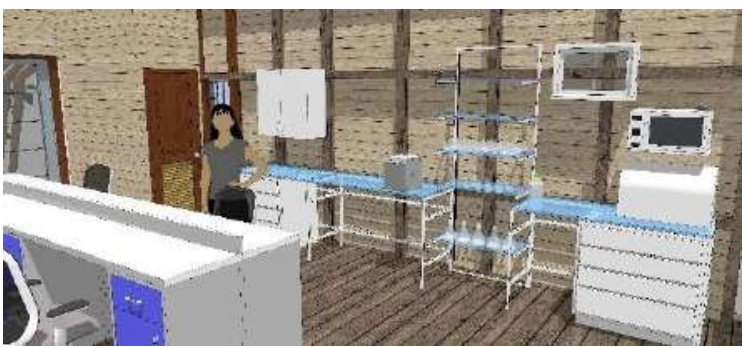

Gambar 25. Ilustrasi interior laboratorium (Sumber: Penulis 2020)

\section{KESIMPULAN}

Stasiun Riset Bekantan pada Lahan Basah merupakan pusat penelitian, pembudidayaan, dan pengembangan kegiatan ilmiah tentang bekantan dan ruang lingkup lahan basah yang di dalamnya juga mewadahi kegiatan restorasi kawasan lahan basah serta ekowisata dengan minat khusus. Stasiun riset tersebut bertujuan menjadi identitas kawasan untuk meningkatkan kelestarian bekantan dan lahan basah sebagai habitat alaminya 
sehingga dapat meningkatkan pula tingkat kesadaran masyarakat tentang bekantan beserta habitat alaminya. Dengan demikian, permasalahan yang diangkat pada perancangan ini adalah bagaimana rancangan stasiun riset bekantan pada lahan basah yang selaras dengan kondisi alam sekitarnya sehingga dapat menjadi identitas kawasan tersebut.

Berdasarkan permasalahan yang diangkat pada perancangan ini, maka metode yang diterapkan dalam menyelesaikan masalah adalah penerapan arsitektur organik yang memadukan ruang dan bentuk dengan lingkungan sekitarnya. Dalam hal tersebut metode arsitektur organik pada perancangan ini memperhatikan karakteristik lingkungan lahan basah untuk diangkat menjadi identitas kawasan sehingga metode tersebut dicapai melalui pendekatan metabolisme, Pendekatan metabolisme tersebut memiliki prinsip utama dalam melindungi kehidupan dengan memberikan solusi dalam memisahkan keperluan manusia dan alam, sedangkan penyelesaian masalah identitas dalam perancangan stasiun riset ini melalui pendekatan identitas visual dengan metode metafora dalam penerapannya. Pendekatan identitas visual tersebut berperan dalam mempertahankan citra kawasan stasiun riset sebagai jembatan yang menyatukan konteks dan manusia dengan tampilan sehingga setiap orang yang melihatnya mendapatkan gambaran yang jelas tentang citra tempat tersebut. Pendekatan tersebut diperkuat dengan metode metafora yang bertujuan untuk mempengaruhi interpretasi pengamat terhadap rancangan dengan berbagai sudut pandang yang berbeda agar menghasilkan arsitektur yang ekspresif.

Dengan demikian, konsep yang dapat diangkat pada Perancangan Stasiun Riset Bekantan pada Lahan Basah adalah konsep "subject-object interaction" yang diwujudkan dalam konsep "wetland ecology". Konsep "subject-object interaction" mengangkat interaksi subjek dan objek penelitian di lahan basah yang di dalamnya juga mencakup interaksi organisme dengan lahan basah seperti bekantan dengan habitat alaminya. Konsep ini bertujuan agar subjek atau peneliti sebagai pelaku dapat merasakan langsung kehidupan bekantan dan ekosistem lahan basah secara nyata, sedangkan konsep "wetland ecology" mengangkat tema ruang lingkup lahan basah yang diterapkan ke rancangan stasiun riset dengan memperhatikan unsur alam di sekitar bangunan sehingga identitas kawasan dapat diperkuat dengan memasukan unsur tersebut ke dalam bangunan. Sebagai perwujudan konsep "subject-object interaction and wetland ecology" yang dipengaruhi oleh metode metabolisme-organik dan metode identitas visual-metafora, maka konsep tersebut terbagi dalam dua aspek, yaitu aspek fisik dan aspek non-fisik. Konsep "wetland ecology" sebagai aspek fisik yang meliputi form, circulation, dan materiil, sedangkan konsep "subject-object interaction" sebagai aspek non-fisik yang meliputi zoning, camouflage, dan continuous.

\section{DAFTAR PUSTAKA}

\section{Referensi Buku dan Jurnal}

Bismark, M. (2009). Biologi Konservasi Bekantan. Pusat Penelitian dan Pengembangan Hutan dan Konservasi Alam.

Christanto, J. (2014). Konservasi Sumber Daya Alam dan Lingkungan.

Ganguly. (2008). What is Organic Architecture.

Harahap, F. R. (2018). Pengelolaan Lahan Basah Terkait Semakin Maraknya Kebakaran dengan Pendekatan Adaptasi yang Didasarkan pada Konvensi Ramsar. Jurnal Society, 40. 
Pascalis, F. (2018). Perancangan Laboratorium Dasar Terpadu Un. Jurnal Online Mahasiswa Arsitektur Universitas Tanjungpura.

Rezeki, Z. d. (2016). Struktur Populasi Bekantan (Nasalis larvatus) di Pulau Curiak Kabupaten Barito Kuala Kalimantan Selatan. Prosiding Symbion (Symposium on Biology Education),, 2.
VOA. (2015). Melindungi Lahan Basah, Melindungi Kehidupan. Diambil kembali dari VOA Indonesia. 